IZA DP No. 4619

\title{
Cultural Diversity and Local Labour Markets
}

Jens Suedekum

Katja Wolf

Uwe Blien

December 2009 


\title{
Cultural Diversity and Local Labour Markets
}

\author{
Jens Suedekum \\ University of Duisburg-Essen \\ and IZA \\ Katja Wolf \\ IAB Nürnberg \\ Uwe Blien \\ $I A B$ Nürnberg, \\ University of Bamberg and IZA
}

\section{Discussion Paper No. 4619 \\ December 2009}

\author{
IZA \\ P.O. Box 7240 \\ 53072 Bonn \\ Germany \\ Phone: +49-228-3894-0 \\ Fax: +49-228-3894-180 \\ E-mail: iza@iza.org
}

Any opinions expressed here are those of the author(s) and not those of IZA. Research published in this series may include views on policy, but the institute itself takes no institutional policy positions.

The Institute for the Study of Labor (IZA) in Bonn is a local and virtual international research center and a place of communication between science, politics and business. IZA is an independent nonprofit organization supported by Deutsche Post Foundation. The center is associated with the University of Bonn and offers a stimulating research environment through its international network, workshops and conferences, data service, project support, research visits and doctoral program. IZA engages in (i) original and internationally competitive research in all fields of labor economics, (ii) development of policy concepts, and (iii) dissemination of research results and concepts to the interested public.

IZA Discussion Papers often represent preliminary work and are circulated to encourage discussion. Citation of such a paper should account for its provisional character. A revised version may be available directly from the author. 
IZA Discussion Paper No. 4619

December 2009

\section{ABSTRACT \\ Cultural Diversity and Local Labour Markets}

During the last decade there have been marked changes in the composition of the non-native workforce in the German labour market. In particular there has been a notable increase in the diversity of nationalities of which the foreign workforce is composed. In this paper we investigate the effects of this diversity for native employees. Our analysis is conducted at the local level and uses a panel of 326 Western German regions over the time period 1995-2006. When considering high-skilled foreign workers, we find that both the size of this group and the diversification into different nationalities raise local wages and employment for native employees. For low-skilled foreign workers we find negative size effects. However, these negative effects can be partly offset if the group of low-skilled foreigners is culturally diversified. Our results imply that diversity raises productivity at the local level, but that it is important to distinguish the skill composition of the foreign workforce. These findings remain robust in a variety of robustness checks that take into account omitted variable bias, selfselection of foreigners into particular regions, and spatial autocorrelation.

JEL Classification: R23, J21, J31

Keywords: regional labour markets, cultural diversity, immigration, spatial equilibrium

Corresponding author:

Jens Südekum

University of Duisburg-Essen

Mercator School of Management

Lotharstrasse 65

47057 Duisburg

Germany

Email: jens.suedekum@uni-due.de

\footnotetext{
* This research was supported by the NORFACE research programme "Migration in Europe - Social, Economic, Cultural and Policy Dynamics". The authors thank Holger Bonin, Fabrice Defever and seminar participants in Aarhus, Bielefeld, Jena, Kiel, Mannheim, New York City, Nürnberg and Trier for very helpful suggestions on earlier drafts of this paper. The authors also thank Anette Haas and Van Phan thi Hong for research assistance. All remaining errors and shortcomings are solely our responsibility.
} 


\section{1.) Introduction}

Germany has one of the largest shares of workers with foreign nationality across all European countries. This share has substantially increased during the early 1990s, mainly due to the fall of the iron curtain and the massive immigration from Eastern Europe. It reached a peak in the years right after the German reunification, but since 1995 the share of foreign workers in total (Western) German employment is roughly stable or even slightly decreasing. Figure 1a shows that about $8 \%$ of all full-time employment relationships subject to social security (the socalled "regular employment relationships") are filled with workers with foreign nationality in the year 2006. However, even though the size of the foreign workforce in the German labour market has remained roughly stable over the time period 1995-2006, there have been marked changes in the composition of this group. Firstly, a relatively well-known trend is that the group of foreign workers has, on average, become more educated over time. Particularly since 1998 there has been an increase in the share of foreign workers with completed tertiary education, and a decline of non-university trained foreigners, as is shown in figure $1 \mathrm{a}$.

\section{FIGURE 1 HERE}

Another compositional change, which is by far not as widely acknowledged in the general public, is that the diversity of the nationalities of which the foreign workforce is composed has risen considerably. Figure 1b depicts a Herfindahl-type diversity index over 180 different foreign nationalities in the total population of foreign workers with a regular employment relationship. ${ }^{1}$ This figure suggests that the German labour market has become more heterogeneous in terms of national and, thus, linguistic and cultural backgrounds.

This paper is concerned with the effects of this cultural diversity (measured by the diversity of nationalities) on the labour market outcomes for native German workers. We use a panel of 326 Western German NUTS3 regions (Landkreise) over the time period 1995-2006 and analyze the wage and employment effects for natives that are associated with the size and the diversification of the foreign workforce at this local level. The main questions that we address are the following: Are German workers more successful in regions with a high share of foreign workers? In particular, for given local shares of foreigners, are there positive or negative effects for the natives when the foreign workforce is heterogeneous in terms of national backgrounds? Through which economic channels do the potential effects of cultural diversity affect the natives? And finally, are there systematic differences in the effects of cultural diversity when distinguishing the foreign workers according to their skill level?

\footnotetext{
${ }^{1}$ See sections 2.3 . and 3 for a description of the data and a formal definition of the index.
} 
In the recent literature there has been a huge interest in the effects of cultural or ethnic diversity on economic performance and various other economic and political outcome variables (see Alesina and La Ferrara, 2005, for a survey). This research spans insights from various fields and has been conducted at different levels. Macroeconomists and growth theorists have, for example, investigated if diversified countries grow faster or slower than homogeneous ones (see, e.g., Spolaore and Wacziarg 2009; Easterly and Levine 1997). Recent work in behavioural, public and development economics has sought to answer the question if teams or village communities perform better (or exhibit more cooperative behaviour, or better political outcomes) with a higher degree of heterogeneity of the group members. Finally, there is also a small number of papers that address the effects of cultural diversity at the regional level, i.e., across cities or counties within the same country (see Glaeser et al., 1995; Alesina et al. 1999, 2000; Florida 2002; Ottaviano and Peri 2005, 2006). Our study is most closely related to this string of literature. ${ }^{2}$

Why should the diversity of the foreign workforce affect native employees at the level of small, local labour markets? In this paper we argue that the impact of diversity may be transmitted through different channels via externalities. Firstly, workers from different cultural backgrounds may embody complementary skills and problem-solving abilities. When these workers interact, productivity may rise due to knowledge spillovers or other forms of production externalities which are known to be strongly localized (Audretsch and Feldmann, 1996). On the other hand, when the fractionalization becomes too strong, this may also imply excessive transaction costs for communication and thus lower local productivity. Secondly, the effects of diversity may also operate through a totally different channel, namely by affecting the quality of life at the local level. A tolerant native population may value a multicultural atmosphere as an attractive feature. Yet, diversity may also be perceived as unattractive if natives fear that social conflicts between different foreign nationalities are imported into their own neighbourhood (Dustmann and Preston 2001). That is, cultural diversity may affect locations, and the natives working therein, both via the production (labour demand) and the consumption (labour supply) side, and the net effect could be either

\footnotetext{
${ }^{2}$ Our paper is also more broadly related to the literature on the labour market effects of immigration. For the immigration wave to Germany prior to reunification, De New and Zimmermann (1994) find some displacement and adverse wage effects for native workers, whereas Pischke and Velling (1997) and Bonin (2005) find little evidence for such negative impacts. Glitz (2007) focuses on ethnic German immigration after reunification and finds some displacement but no wage effects. D`Amuri et al. (2009) differentiate foreigners and natives by skill and experience level. They argue that displacement effects arise, if at all, only for previous migrants but not for native workers. Brücker and Jahn (2009) study the wage effects of migration. None of these papers is concerned with the effects of the cultural heterogeneity of the group of foreigners, however. An overview of the issues of German immigration is provided by Zimmermann et al. (2007). Dustmann and Glitz (2005) and Friedberg and Hunt (1995) survey the general literature on the labour market impacts of immigration. Further important contributions to that literature include Borjas (1994) and Card (2001).
} 
positive or negative. To address these various possibilities we use an estimation framework that is based on the spatial equilibrium model by Roback (1982). Within this framework we recover the direction of the net impact of cultural diversity, and the channel through which it affects natives from regional wage and employment regressions.

Our paper adds value to the literature on the effects of cultural diversity at the local level in at least three important respects. First of all, almost the entire literature has looked at US cities and metropolitan areas. For example, in two influential studies, Ottaviano and Peri (2005, 2006) find that fractionalization of local populations into groups with different primary languages spoken at home is robustly positively related with average wages, land rents and employment density across US metropolitan areas. This suggests that cultural diversity (here measured by a diversity index of primary languages) raises local productivity in the US. It is not clear, however, if these results are representative for other countries. One has to keep in mind that the United States are the classical immigration country. The major US cities always have been "melting pots" and the most favourite destinations for migrants from all over the world. For many European countries, including Germany, immigration laws were largely based on different priorities, and migration inflows have been considerably smaller (Zimmermann 2005). Moreover, labour market institutions in Germany and the US exhibit non-negligible differences. ${ }^{3}$ It is therefore an open issue if positive local effects of cultural diversity, as found for the US case, also arise in a continental European context.

The second and most important contribution of this paper is to provide an analysis that pays close attention to the skill composition of the foreign workforce. The previous literature has mainly studied the labour market effects for native employees that are associated with the cultural diversification across all foreign workers. We separately study the effects for the natives that are associated with the size and the diversification of the groups of high-skilled and low-skilled foreign workers, respectively. ${ }^{4}$ Such a more disaggregated approach seems quite natural. If there is a consumption value of diversity for the natives, this value may be quite different depending on whether diversity refers to the group of high-skilled or lowskilled foreigners. Similarly, when there are inter-cultural learning and knowledge spillovers, which possibly make locations more productive, it may require a certain education level on the part of the foreigners in order for these production externalities to materialize.

\footnotetext{
${ }^{3}$ Schmidt et al. (1994) show that the effects of immigration into labour markets with high unionisation rates are quite different from the effects of immigration into "flexible" labour markets.

${ }^{4}$ In their main theoretical and empirical analysis, Ottaviano and Peri $(2005,2006)$ implicitly treat all nonEnglish speaking workers as equally skilled. In a robustness check, Ottaviano and Peri (2006) control for the average education of the foreign population, but they do not systematically distinguish the effects of the diversity of skilled versus low-skilled foreign workers.
} 
Finally, our third contribution is methodological. In our empirical analysis we address a number of estimation concerns and provide a variety of robustness checks. One major potential problem is spatial autocorrelation. The administrative regions that form the units of observation in our study are unlikely to be independent, but spatially correlated amongst each other. As is well known since Anselin (1988), spatial autocorrelation can lead to biased and inefficient estimates. To address this issue we make use of recent progress from the spatial econometrics literature and present one of the first applications to panel estimation with regional fixed effects. Secondly, we use instrumental variable techniques in order to address the causal effect of diversity for the labour market outcomes of natives. Clearly, foreign workers may self-select into particular regions, and the local diversity level may be driven by local productivity rather than the other way around. Furthermore, cultural diversity may be measured with error when using standard fractionalization indices. To address these issues, we treat cultural diversity as an endogenous variable and use various instruments in order to correct for the bias that would plague OLS estimations.

Let us briefly preview our main results. For the group of high-skilled foreign workers we find that both group size (share in total high-skilled employment) and diversity raise local productivity. As for the size of the group of low-skilled foreigners, we find negative wage and employment effects. Yet, there are still positive productivity effects for given group sizes if the low-skilled foreigners are diversified into many different nationalities.

More generally, our results suggest that positive labour market effects of cultural diversity do in fact exist in Germany, and that they affect natives mainly through the production (labour demand) side of the market. Importantly, however, one has to distinguish foreign workers with different skill levels to get the overall picture. Diversity seems to be unconditionally beneficial for the case of high-skilled foreign workers. Ceteris paribus, the more high-skilled foreigners work in a region, the higher is local productivity, especially if this group consists of people from various nationalities. With respect to low-skilled foreign workers, diversity per se is also beneficial for productivity. To quantify the overall impact of low-skilled foreigners on natives, however, one has to take the negative size effects into account as well. The most adverse labour market effects for the natives are to be expected in regions that host a large and culturally homogeneous group of low-skilled foreign workers.

The rest of this paper is structured as follows. In section 2 we discuss some theoretical background and present an organizing framework that guides the estimations. Section 3 describes the data. Our main results are introduced in section 4. Section 5 is devoted to robustness checks. Section 6 concludes and draws some policy implications. 


\section{2.) Theoretical background and estimation framework}

\subsection{Theory}

Our approach to identify the regional effects of cultural diversity is based on the seminal spatial equilibrium concept by Roback (1982). Consider a country that consists of $r=1,2, \ldots, N$ locations. There are two goods, a freely tradable commodity $Y$ which is produced under constant returns to scale, and a non-tradable stock of land $R$ which is in fixed supply in every region and owned by absentee landlords. Firms in the $Y$-sector use labour and land in production and are perfectly mobile across space. Workers are also perfectly mobile across space and consume residential land and the tradable good $Y$. For simplicity it is assumed that consumer preferences are homothetic, so that expenditure patterns are independent of income. The total number of workers in this economy is given by $L=\sum_{r} L_{r}$.

All markets are perfectly competitive and always clear in equilibrium. The tradable good $Y$ is used as the numéraire and its price is normalized to one. The price of land in region $r$ is denoted by $p_{r}$, which follows implicitly from equating the (fixed) supply of land and the demand for land which is driven by local population sizes. A crucial assumption is that the locations offer different productive and consumptive amenities, respectively affecting the location decisions of firms and workers. The utility level of a worker in region $r$ is denoted by $U_{r}$. With homothetic preferences utility can be specified such that it depends on the nominal equilibrium wage $\left(w_{r}\right)$, on the supply of land $\left(R_{r}\right)$, on the number of workers located in that region $\left(L_{r}\right)$, and on the local consumptive amenity of region $\mathrm{r}\left(A_{r}^{C}\right)$, i.e., $U_{r}\left(w_{r}, L_{r}, R_{r}, A_{r}^{C}\right)$. Similarly, with constant returns in production, the profit level of a firm in region $r$ can be written as $\pi_{r}=\pi_{r}\left(w_{r}, L_{r}, R_{r}, A_{r}^{P}\right)$, where $A_{r}^{P}$ denotes the level of the productive amenity of location $r^{5}{ }^{5}$ We can then define a spatial equilibrium as follows:

\section{Definition 1: Spatial equilibrium}

A spatial equilibrium is a sequence of prices $\left\{w_{1}, \ldots, w_{N}\right\},\left\{p_{1}, \ldots, p_{N}\right\}$ and an allocation of workers $\left\{L_{1}, \ldots, L_{N}\right\}$, such that, given the local supplies of land $\left\{R_{1}, \ldots, R_{N}\right\}$ and the values of the amenities $\left\{A_{1}^{C}, \ldots, A_{N}^{C}\right\}$ and $\left\{A_{1}^{P}, \ldots, A_{N}^{P}\right\}$ :

\footnotetext{
${ }^{5}$ Alternatively we could explicitly solve for the equilibrium price of land $\mathrm{p}_{\mathrm{r}}$ and specify utility and profit levels as functions of wages $\mathrm{w}_{\mathrm{r}}$, land prices $\mathrm{p}_{\mathrm{r}}$ and amenities. We prefer our identification approach that uses wage and employment regressions, because the available German data for housing and land prices are far less reliable than our very accurate official employment data.
} 
1.) Utility levels are equalized across space

2.) Profit levels are equalized across space

3.) All markets clear.

$$
\begin{aligned}
& U_{k}(\cdot)=U_{\ell}(\cdot)=\bar{U} \quad \forall k, l \in[1, \ldots, N] \\
& \pi_{k}(\cdot)=\pi_{\ell}(\cdot)=\bar{\pi} \quad \forall k, l \in[1, \ldots, N]
\end{aligned}
$$

Figure 2 illustrates the concept of spatial equilibrium. Think of one particular city $r=1$. We can invert the profit function $\bar{\pi}=\pi_{1}\left(w_{1}, L_{1}, R_{1}, A_{1}^{P}\right)$ and derive a labour demand schedule $\mathrm{L}^{\mathrm{D}}$ that is downward sloping in the $(w, L)$-space with parameters $\bar{\pi},\left\{R_{1}, \ldots, R_{N}\right\}$ and $\left\{A_{1}^{P}, \ldots, A_{N}^{P}\right\}$. This function shows the combinations of local wages and employment such that the firms in this location are just indifferent between staying and moving to a different region, given the exogenous stocks of land and the amenity levels of all regions in this economy. Similarly, the utility function $\bar{U}=U_{1}\left(w_{1}, L_{1}, R_{1}, A_{1}^{C}\right)$ can be inverted to yield an upward sloping labour supply schedule $\mathrm{L}^{\mathrm{S}}$ with parameters $\bar{U},\left\{R_{1}, \ldots, R_{N}\right\}$ and $\left\{A_{1}^{C}, \ldots, A_{N}^{C}\right\}$.

The point $\mathrm{X}$ in figure 2 is consistent with a spatial equilibrium: wage and employment (density) in city 1 is endogenously determined as $w_{1}$ and at $L_{1}$, respectively, given the profit and utility level that could be obtained in other locations ( $\bar{\pi}$ and $\bar{U}$ ). Now consider an increase of the productive amenity of region $1\left(A_{1}^{P}\right)$. At any employment level firms in that region could pay higher wages without being induced to leave: the $\mathrm{L}^{\mathrm{D}}$-curve shifts outwards. To restore spatial equilibrium, both wage and employment in city 1 must go up. This is illustrated by the movement from point $\mathrm{X}$ to point $\mathrm{Y}$ in figure 1. Since land supply is fixed, there is also an increase in the equilibrium price of land as more firms and workers move in. An increase in the consumptive amenity $A_{1}^{C}$, on the other hand, would cause the $\mathrm{L}^{\mathrm{S}}$ schedule to shift down: For any level of employment individuals are willing to work at lower wages, due to the higher quality of life in that location. The new equilibrium would involve a lower wage in city 1, but a higher employment level (and thus, higher land rent). This is illustrated by the movement from point $\mathrm{X}$ to point $\mathrm{Z}$ in figure 2 .

Hence, both types of (positive) amenities increase employment (and thus capitalize in higher land prices), but productive amenities imply higher wages whereas consumptive amenities imply lower wages. An equivalent thought experiment is the following: Consider point $\mathrm{X}$ as the level of wages and employment in city 1. Now suppose we observe a second city ( $r=2)$ that has an identical supply of land but a higher employment density (and thus, higher land 
rent). Figure 2 suggests that city 2 either has a higher productive, or a higher consumptive amenity, or a combination of the two. The first case is associated with higher wages (point $\mathrm{Y}$ ), the second case with lower wages in city 2 (point Z), and for the third case it depends on which type of amenity is stronger. Wage and employment regressions can thus be used to recover the net effect of productive and consumptive amenities across cities.

\section{FIGURE 2 HERE}

What precisely determines the productive and consumptive amenities of a location? Various candidates such as weather, landscape, local infrastructure, etc., have been considered in the literature. In this paper we hypothesize that the cultural diversity of a city can also be regarded as such a location characteristic. Given the previously mentioned evidence on the relatively small direct displacement effects in the German labour market (Bonin 2005, D'Amuri et al. 2009), we thus assume that natives and foreigners do not directly compete for the same types of jobs in the market, but that the foreign workforce nevertheless affects the labour market outcomes for natives via external effects. It is, however, not clear if diversity mainly affects the labour demand or the labour supply side, and whether the net impact is positive or negative. For each of the cases there exist sensible economic theories, which we now briefly discuss in turn.

A) Diversity may be a positive productive amenity: A culturally diversified stock of foreigners may raise local productivity, because it enriches the variety of culture-specific skills or problem solving abilities, which in turn fosters innovation.

B) Diversity may be a negative productive amenity: At the same time, diversity may also lower productivity because it increases communication costs which naturally arise if people of different cultural backgrounds have to interact and to work together on projects.

The trade-off of heterogeneity as a productive (dis-)amenity has, for example, been described in a formal model by Berliant and Fujita (2008). In that model knowledge creation or innovation requires interaction between individuals. The potential innovators need some nonoverlapping prior knowledge, because people with identical background cannot learn from each other. At the same time the individuals also need some overlapping stock of knowledge since they otherwise have no common basis for communication. Berliant and Fujita (2008) do not explicitly distinguish between foreigners and natives, but the trade-off described in their 
model also applies to the productivity effects of cultural diversity at the local level: Some diversity may raise productivity because it goes hand in hand with sufficiently differentiated initial stocks of knowledge. Too much diversity, on the other hand, may lead to lower productivity because communication becomes too costly. ${ }^{6}$ Positive productivity effects of diversity are also often included directly in the production function. Here it is typically assumed that different ethnic or cultural groups represent distinct input factors, and that these inputs are combined in a production process that exhibits increasing returns to variety (mostly a CES function), see e.g. Alesina and La Ferrara (2005), Ottaviano and Peri (2005). Also, gains of productivity are possibly due to a higher degree of innovation mediated by a diverse workforce (see Niebuhr, forthcoming). These potential productivity enhancing effects can then be countervailed by transaction costs of communication. The latter point is made explicit in Lazear (1999) who discusses the diversity of languages in a multicultural society. In his model individuals can only engage in economic transactions if they speak the same language. That is, linguistic and cultural fragmentation lowers productivity because people cannot communicate and trade.

Turning to the second possible channel, diversity may also be a location characteristic that mainly affects private location decisions of individuals:

C) Diversity may be a positive consumptive amenity: A diversified multicultural environment may be perceived as an attractive regional attribute by a tolerant native population.

D) Diversity may be a negative consumptive amenity: Diversity may, however, also be perceived as an unattractive location characteristic, because the natives fear foreign infiltration that gives rise to social conflict between too many different nationalities, etc.

Suppose that the single cultural groups also produce differentiated ethnic goods, and that natives have a CES-type utility function that exhibits love for variety. Suppose for simplicity that these ethnic goods are non-tradable. It is then easy to see that diversity in a region raises utility, because of a higher variety of cultural goods in a diverse region. At the same time there is abundant work in development and public economics showing that individuals often distrust members of other ethnic groups and tend to prefer interacting in culturally relatively homogeneous communities (see Glaseser et. al. 2000; Alesina and La Ferrara 2002). These

\footnotetext{
${ }^{6}$ A similar question is analyzed in Hong and Page (2001) who consider individual and collective problem solving of heterogeneous individuals.
} 
two forces thus operate into different directions, so that it is unclear if people associate a positive or negative overall consumption value with the cultural diversity of a location.

The rationale for distinguishing between the diversity of high-skilled and low-skilled foreign workers, which is one of the main contributions of this paper, relates directly to this theoretical framework. It is well conceivable that skilled and low-skilled foreign workers affect regional productive and consumptive amenities very differently. A positive impact of diversity on productivity may require a certain skill level of the foreign workers. Similarly, the consumption value of a multicultural environment may also depend on how educated the group of foreigners is. We therefore distinguish explicitly the diversity of the group of highskilled foreign workers in a region, and the diversity of the low-skilled foreigners.

\subsection{Estimation framework}

The theoretical framework outlined above suggests that wage and employment regressions for native German workers are well suited to disentangle the net effect of cultural diversity at the local level. We use the following specification for the empirical model:

$$
\begin{aligned}
& \ln \left(\text { wage }_{r, t}\right)=\alpha_{r}^{\text {wage }}+\alpha_{t}^{\text {wage }}+\beta^{\text {wage }} \cdot \operatorname{div}_{r, t}+\gamma^{\text {wage }} \cdot X_{r, t}+\varepsilon_{r, t}^{\text {wage }} \\
& \ln \left(e m p_{r, t}\right)=\alpha_{r}^{e m p}+\alpha_{t}^{e m p}+\beta^{\text {emp }} \cdot \operatorname{div}_{r, t}+\gamma^{e m p} \cdot X_{r, t}+\varepsilon_{r, t}^{e m p}
\end{aligned}
$$

$e m p_{r t}$ is employment and $w_{r t}$ is the average wage for native workers in city $\mathrm{r}$ and time t. $d i v_{r t}$ measures cultural diversity and refers to the foreign workers in region $r$. The precise specification of $d i v_{r t}$ for the empirical analysis is discussed below. $X_{r t}$ are additional control variables (such as the firm size, industry and skill composition of the native population), the $\alpha$ 's are time and region fixed effects, and the $\varepsilon$ 's are error terms. ${ }^{7}$

The central coefficients of interest are $\beta^{\text {wage }}$ and $\beta^{\text {emp }}$. If diversity is a positive production amenity we should find positive wages and employment effects $\left(\beta^{\text {wage }}>0, \beta^{\text {emp }}>0\right)$. A negative production amenity would imply negative signs of both coefficients. If diversity is a positive consumption amenity we should find positive employment and negative wage effects ( $\beta^{\text {wage }}<0, \beta^{\text {emp }}>0$ ). If it is a negative consumption amenity, there must be a compensating wage differential ( $\left.\beta^{\text {wage }}>0\right)$ and negative employment effects $\left(\beta^{\text {emp }}<0\right)$.

\footnotetext{
${ }^{7}$ Notice that we could have specified employment density ( $e m p_{r, t} /$ area size) as the dependent variable in (2), which is equivalent since time-invariant area sizes are captured by the regional fixed effects. The theoretical framework also suggests that we must always control for regional supply of housing, as the model assumes a fixed supply of land. In the regressions below we always control for $R_{r}$.
} 


\subsection{Measurement of diversity}

In the estimations we include two variables related to the foreign labour market participation. Firstly, we control for the share of foreign workers in total area employment, i.e.

$$
s_{r, t}=\text { foreigners }_{r, t} / e m p_{r, t}
$$

This variable measures the size of the group of foreign individuals who work in region $r$ at time t. The second variable then specifically measures the degree of diversification of the stock of foreigners into different nationalities. We use a diversity index that is based on the standard Herfindahl-Hirshman index $\left(h h i_{r t}\right)$. Our index is defined in the following way:

$$
\text { hhi }_{r, t}=1-\sum_{k=1}^{K}\left(\frac{\text { foreigners }_{k, r, t}}{\text { foreigners }_{r, t}}\right)^{2},
$$

where group $k=1,2, \ldots, K$ indexes the different foreign nationalities. This index takes on values between 0 and 1 and stands for the probability that two randomly drawn foreign employees belong to two different nationalities. If all foreigners in region $r$ have the same nationality we would have $h h i_{r, t}=0$, and the index then increases in the degree of diversity. ${ }^{8}$ The correlation between $s_{r, t}$ and $h h i_{r, t}$ in the data turns out to be rather modes $(\rho \approx 0.2)$, which allows us to control for both variables at the same time and, thus, to separate fractionalization and size effects of the foreign workforce. More formally, in the equations (1) and (2) we typically use the specification $\beta^{\text {wage }} \cdot \operatorname{div}_{r, t}=\beta_{1}^{\text {wage }} \cdot s_{r, t}+\beta_{2}^{\text {wage }} \cdot h h i_{r, t}$ and $\beta^{\text {wage }} \cdot \operatorname{div}_{r, t}=\beta_{1}^{\text {emp }} \cdot s_{r, t}+\beta_{2}^{\text {emp }} \cdot h h i_{r, t}$. When we explicitly distinguish the group of foreign workers in region $\mathrm{r}$ by their skill level, we replace $s_{r, t}$ by the share of high-skilled (lowskilled) foreign workers in total regional high-skilled (low-skilled) employment. Furthermore, we then separately measure the diversity index $h h i_{r, t}$ for the sub-population of high-skilled (low-skilled) foreign workers in region $\mathrm{r}$.

\section{3.) Data and descriptive overview}

\subsection{Data issues}

The data basis for this study is provided by the Institute for Employment Research (IAB). It includes the complete population of full-time employment relationships subject to social

\footnotetext{
${ }^{8}$ For robustness checks we have also considered an entropy index as an alternative diversity measure. The estimation results for the entropy index turn out to be very similar as for the Herfindahl-index.
} 
security (i.e. excluding civil servants and self-employed individuals), aggregated at the level of the 326 Western German NUTS3-districts (“Landkreise” and "kreisfreie Städte”).

Several remarks are in order about this data set. First of all, it contains information drawn from the official German employment statistics by the Federal Employment Agency which is used in the administration of the social security system. The data is therefore highly reliable as unit non-response and measurement error are reduced to a minimum. It is available as a balanced panel on an annual basis (1995-2006). For every region and every year we also have detailed additional information about structural characteristics of the local native workforces, such as industrial composition, qualification, firm size, age and gender structure of regional employment. This information will be used to construct further control variables which we include in order to avoid omitted variable bias for our central coefficients of interest.

Still there are a few limitations that we have to face. Firstly, we measure regular employment at the regional level. I.e., foreigners as well as natives enter our data set only if they work full time and pay social security contributions. On the one hand this seems to be appropriate as we are interested in the labour market effects of cultural diversity. Yet, some of the above mentioned theoretical mechanisms may actually depend on the size and composition of the local foreign population, rather than on the sub-population of foreigners who work full time. Since foreign population and employment are strongly correlated, however, we believe that the use of our data set does not lead to any systematic errors or biases.

The second data issue concerns the definition of native and foreign workers, namely that we proxy culture with the recorded nationality of an individual. We can measure the latter in a very detailed way, as more than 180 different foreign nationalities can be distinguished. Nationality is still only an imperfect measure of culture, however. First of all, there is naturalization of immigrants who obtain German citizenship subject to certain restrictions, even though overall naturalization rates are quite low (see D'Amuri et al., 2009). Naturalization, which is particularly relevant for the ethnic German immigrants, implies that these individuals are recorded as native workers, even if they are not "culturally assimilated" in any meaningful way. Second-generation migrants also often have German nationality although they may be culturally closer to their parents' country of origin. An alternative approach would be to measure culture by the primary language spoken at home, or by a similar variable. This would mean abandoning the use of official employment data, however, which does not include such information. We would have to use survey data instead, which is of substantially lower quality in other respects, especially when conducting an analysis at the 
regional level. Hence we decided to use of official labour market data while hoping that the associated data problems of measuring culture are not too severe. ${ }^{9}$

The next data issue concerns the wage information for native workers, which will be used as one of our dependent variables. For every region and every year we compute the average daily wage income per employee, including all bonuses and extra payments subject to social security. The underlying micro-data for individual wage earnings have the problem that income levels which exceed the threshold for social security contributions are reported with this value. The data therefore understates the true degree of wage dispersion in Western Germany. There have been experiments at the IAB to estimate and to impute true wage earnings for individuals at the income threshold, but it turns out that this procedure has only minor effects on the distribution of regional average wages. Since our study uses average regional wages only, we are confident that our data is reasonably accurate also in this respect. The final data issue is the classification of regions in our data set. We use administrative regions (NUTS3) which are not defined according to economic criteria. This raises the concern that some of our results may be artefacts of the choice of these units. Below we consider spatial econometric techniques to explicitly take spatial autocorrelation into account.

\subsection{Descriptive overview}

Before turning to the estimation results we give a brief descriptive overview about the participation of foreign workers in this section. In table 1 we report the ten nationalities with the largest employment shares in Western Germany for the years 1995 and 2006, respectively.

\section{TABLE 1 HERE}

As can be seen, the Turkish employees form the largest foreign group, followed by employees from the former Yugoslavia, Italy, and Greece. This ranking is very persistent over the years, and reflects longer historical incidents that can be traced back to the mid-1950s. The first large wave of immigration after WWII was caused by a shortage of labour that characterised the post-war economic boom. Various industries obtained the permission to hire foreign "guest workers", in order to fill low-paid positions for which it was difficult to find German applicants. Turkey, Yugoslavia, Italy and Greece have been the countries where most guest workers were recruited. Originally the intention has been to issue only temporary work permits, and that the guest workers return to their countries after a certain period, but this was

\footnotetext{
${ }^{9}$ See Desmet et al. (2009) for a recent contribution about how "cultural diversity" can be defined in a meaningful way, by making use of very long-term linguistic data about language trees.
} 
never strictly enforced. Quite the contrary, many former guest workers became assimilated in Germany and reunified with their families.

\section{FIGURE 3 HERE}

\section{TABLE 2 HERE}

Turning to the regional level, the map in figure 3 illustrates the total shares of foreign employees in 2006. The largest shares are found in the metropolitan areas in the southern part of the country (around Stuttgart, Frankfurt and Munich) and in the Rhine-Ruhr area in the West. The share of foreign workers is below $1 \%$ in several other, more rural areas in the North. In table 2 we report further information for the seven largest cities in Western Germany (in terms of total regional employment). Except for Hannover, all large cities have above-average total shares of foreign workers. Table 2 also suggests that the foreign workforces in large cities tend to be relatively highly skilled compared to the Western German average, Hannover again being the exception. Finally table 2 reports the diversity index of the foreign workforce in the selected large cities. Notice at first that the high-skilled foreign population is more diverse than the foreign population in general. This is due to the fact that foreigners of certain nationalities (particularly Western European and North American) are likely to be high-skilled if they work in Germany. Furthermore, urban foreign workforces tend to be more diverse than rural ones, as the total diversity index tends to range above the average for the large cities. This is also true when focussing only on the diversity of the skilled foreign workforce.

\section{4.) Results}

\subsection{All foreign workers}

Table 3 presents the benchmark results for the wage and employment regression, eqs. (1) and (2), where we do not distinguish the skill level of the foreign workforce. In the first column of the wage regression we only control for the total share of foreign born workers $\left(s_{r, t}\right)$, for their degree of cultural diversification as measured by the Herfindahl-index ( $\left.h \mathrm{hi}_{r, t}\right)$, for area and time period fixed effects, and for overall regional housing supply $R_{r, t}$ as measured by the number of housing units. In these specifications we leave out all additional control variables that pertain to structural characteristics of the native workforces. 
We find highly significant negative wage effects from the total share of foreign workers. The diversity index on the other hand is positively associated with average wages for the natives. That is, wages are lower in German regions with a large share of foreign workers, but for a given share wages are higher if the foreign workforce is diversified into many nationalities. In column 2 we include an index of regional industrial diversity, more precisely a Herfindahlindex of regional employment shares across 28 different industries, as well as the broad regional employment shares of manufacturing and service industries (leaving primary industries and the public sector as the excluded reference categories). The reason for including local industrial diversity is that cultural diversity might simply capture occupational heterogeneity as many industries which are prone to hiring a diverse body of (specialist) foreign workers are likely to be concentrated in major cities. By conditioning our estimates on the local industrial structure in this way, we decrease the concern of measurement error or omitted variable bias. As can be seen, the findings for the central coefficients of interest remain robust. Although wages tend to be higher in regions with industrial diversity, there is still an independent and significantly positive effect of the cultural diversity of the foreign workforce. In column 3 we add several further standard control variables that pertain to the qualification, firm size, sex, and age structure of the regional native workforces. The estimated coefficients for these characteristics all have the expected sign and are precisely estimated. With respect to our main coefficients of interest, we find that the negative wage effect for the total share of foreign workers diminishes. This suggests some correlation with the regional control variables for native workers. The effect remains highly statistically significant, however. Similarly, the diversity index exerts a smaller but still significantly positive effect on native wages.

The specification of the regression model raises the concern that the labour market outcomes for natives can be affected by further, unobservable factors that are left out of the regression. Notice, however, that we include regional fixed effects so that all time-invariant local characteristics are controlled for. Still, there could be time-varying regional shocks that affect both native labour market outcomes and foreign diversity levels. This would lead to positive but spurious correlation between the two variables. We address this issue by including the net immigration rate of working-age native individuals in region $r$ and year $t$, because unobserved regional shocks would affect regional migration patterns, which in turn would be the central 
economic force to absorb these shocks. As can be seen in column 4 of table 3, however, all our main findings remain robust to this control for unobservable regional shocks.

Notice further that the regional fixed effects $\alpha_{r}^{\text {wage }}$ also reduce the estimation concern of reverse causality. That problem can arise, because foreigners may self-select into particular locations, presumably into high wage regions. In other words, wages might drive diversity rather than the other around. ${ }^{10}$ One should keep in mind, however, that identification of our regression model rests on the changes in diversity over time. This takes a first cut at the endogeneity issue, since changes in diversity are less likely to be endogenous to the contemporaneous changes in native wages. To demonstrate this point, we have considered a version of specification (4) where we drop the regional fixed effects $\alpha_{r}^{\text {wage }}$ and run a pooled cross-sectional (OLS) analysis. For the share of foreign workers we now obtain a positive and highly significant coefficient $\beta_{1}^{\text {wage }}=0.9066$ (std. error 0.017 ), which confirms that a standard OLS analysis leads to biased estimates. For the diversity index we obtain $\beta_{2}^{\text {wage }}=0.1028$ (std. error 0.006) in the pooled OLS regression. In section 5 we further address self-selection of foreigners into high wage locations by treating $\operatorname{div}_{r, t}$ as an endogenous variable and using instrumental variable techniques.

Turning to the results of the employment regression in columns 5 and 6 of table 3, we find a negative and highly significant effect arising from the total share of foreign workers on native employment $\left(\beta_{1}^{\text {emp }}<0\right.$ ). As for the impact of diversification, the effect on native employment is positive and statistically significant $\left(\beta_{2}^{\text {emp }}>0\right)$. Both results are robust regardless of the set of additional regional control variables, and regardless of whether we additionally control for net immigration rate of natives as our proxy for unobserved regional shocks.

Our results are only partly consistent with those of Ottaviano and Peri (2005, 2006), who have investigated the labour market effects of cultural diversity across US metropolitan areas. These authors consider the effects of diversification across all foreign workers (whose main language is not English), without differentiating the foreigners by their skill level. They find that overall diversity is positively related with wages and employment/land prices for the native (English speaking) individuals. Our findings confirm these results only conditional on the size of the regional foreign workforces. Taking the results of table 3 literally, we would

\footnotetext{
${ }^{10}$ Glitz (2007) exploits the fact that some immigrants, namely the ethnic Germans from Eastern Europe, have been randomly assigned to different locations in Germany. This unique setting allows him to view this immigration wave as a quasi-natural experiment. In many other instances the location choice of foreigners within Germany is not random, however, which forces us to worry about self-selection of the foreigners.
} 
have to conclude that regional productivity is lower the larger is the overall share of foreign workers, because we find negative wage and employment effects $\left(\beta_{1}^{\text {wage }}<0\right.$ and $\left.\beta_{1}^{\text {emp }}<0\right)$. These negative productivity effects are only partly offset if the foreign population is sufficiently diversified into many different nationalities. We do not believe that this interpretation is sensible, however, precisely because the estimations do not distinguish the group of foreigners into high-skilled and low-skilled workers. The results reported in table 3 are thus likely to capture a net effect that masks more specific impacts of foreign workers with different skill levels. We now turn to this issue in a more detailed analysis.

\subsection{Foreign workers differentiated by skill level}

In table 4 we report the results for the wage and employment regressions for native workers when controlling separately for the share and the diversification of high-skilled and lowskilled foreign workers, respectively. We use the same set of control variables as in column 3 of table 3 and exchange $s_{r, t}$ with $s_{r, t}^{\text {skilled }}$ (table 4a) or with $s_{r, t}^{\text {unsilled }}$ (table $4 \mathrm{~b}$ ). Furthermore, we now use the diversity index $h i_{r, t}$ for the sub-populations of high-skilled (low-skilled) foreigners separately. For expositional purposes we only report the results for our central explanatory variables and omit the other estimated coefficients, since they turn out to be very similar as before.

\section{TABLE 4 ABOUT HERE}

For the group of high-skilled foreign workers with completed tertiary education we now find that both their total share in regional high-skilled employment, and their diversification in terms of nationalities are associated with positive wage and employment effects for the native workers. All estimated coefficients are highly significant at the $1 \%$ level and robust to including the regional immigration rate of natives (see specifications 3 and 4). These results suggest that a skilled foreign population is a productive amenity for a German region. The larger is the share of high-skilled foreign workers, the higher is regional productivity and the higher are, thus, average regional wages and employment for the natives. This positive impact is reinforced if the population of high-skilled foreigners is heterogeneous in terms of nationalities. In other words, everything else equal, we find that regional productivity is highest in regions that host a large and heterogeneous group of high-skilled foreign workers. ${ }^{11}$

\footnotetext{
${ }^{11}$ It should be noted that our empirical framework identifies the net effects of cultural diversity. A large skilled foreign population may also have a consumption value for the native population. If this is so, this consumption value capitalizes in lower wages, and the observed positive wage effect even underestimates the true productivity
} 
With respect to the group of low-skilled foreign workers results are different. The larger is the share of low-skilled foreign employees in a region, the lower is the average wage and the lower is employment for the natives. Hence, the size of this group of low-skilled foreign workers can be interpreted as a negative production amenity from a regional perspective. Still, for a given size of the low-skilled foreign population, we still find positive effects associated with the diversification of this group. This means that a region with a large share of lowskilled foreign workers (call it "region 1") need not be less productive than an otherwise similar region with a smaller share of low-skilled foreigners ("region 2"), provided the foreign population in region 1 is sufficiently more heterogeneous than in region 2 . The most adverse labour market effects for native workers are to be expected in regions with a large and culturally homogenous group of low-skilled foreign workers. These results are again robust to including further controls, including the regional immigration rate for natives.

In sum, the main message of this section is that native employees are affected quite differently from the presence of high-skilled and low-skilled foreign workers. The size of the former group has positive, whereas the size of the latter group has negative productivity effects on local labour markets in Western Germany. A study that only looks at the overall group of foreign workers is unable to capture this important distinction. For both high-skilled and lowskilled foreign workers, however, we find positive productivity effects associated with the diversity of nationalities. Thus, cultural diversity has positive productivity effects in Western Germany - unconditionally in the case of high-skilled foreign workers, and conditional on size in the case of low-skilled foreign workers.

\section{5.) Robustness checks}

In the remainder of this paper we address the robustness of these main results. Specifically, in section 5.1 we address the issue of spatial autocorrelation, and in section 5.2 we address potential endogeneity concerns in greater detail.

\subsection{Spatially correlated errors}

We have so far treated the regional units as if they were independent of each other. However, as we use administrative regions, it is likely that there exist cross-regional spillovers and thus spatial dependence across the single units. To account for this issue we make use of spatial econometric techniques. More specifically, we assume a spatial AR(1)-process for the error 
term, which is the standard Cliff and Ord type parameterization in this context (Anselin 1988; Kapoor et al. 2007):

$$
\varepsilon_{r t}=\rho \cdot \sum_{p=1}^{N} w_{p r} \varepsilon_{p t}+v_{r t},
$$

where $\sum_{p=1}^{N} w_{p r} \varepsilon_{p t}$ is the spatial lag of the error process, $\rho$ is the spatial autoregressive parameter and $v_{r t}$ denotes an i.i.d. error term with zero expectation and variance $\sigma_{v}^{2}$. Stacking the error term for period $t$ gives:

$$
\boldsymbol{\varepsilon}_{t}=\rho \mathbf{W} \boldsymbol{\varepsilon}_{t}+\mathbf{v}_{t}
$$

The matrix $W$ is the spatial row-normalized weighting matrix of dimension $N \times N$ and collects the weights $w_{p r}$. In our case we use a simple contiguity matrix. We define the weights as equal to unity if two regions share a common border and zero otherwise. As usual, we do not consider any region to be its own neighbour.

To estimate the unknown parameter $\rho$ we follow Kapoor et al. (2007) by using a GMestimator. However, in contrast to their approach we specify a panel model with fixed instead of random effects. Therefore, we apply a modified estimator which has been proposed by Mutl and Pfaffermayr (2008). This GM-estimator makes use of only the three first moment conditions of Kapoor et al. (2007). Starting point for the GM-estimation are the estimated residuals from a consistent FE-estimation. With a consistent estimator for $\rho$ at hand we transform the models (1) and (2) by pre-multiplication with $\left(\mathbf{I}_{T} \otimes\left(\mathbf{I}_{N}-\hat{\rho} \mathbf{W}\right)\right)$. The resulting error term is spatially uncorrelated. In the last step we compute the FE-estimator for the coefficient vector of the transformed models. Table 5 reports the estimation results.

\section{TABLE 5 ABOUT HERE}

In the wage regressions we obtain consistent results. Concerning the size effects of the foreign workforce on the average wage of native employees we still see the difference between highskilled and low-skilled foreigners: For the former group we obtain positive, for the latter we obtain negative wage effects. The diversity index has a positive and highly significant effect, both with respect to high-skilled and low-skilled foreign workers. All these results are robust to controlling for spatially correlated unobserved regional shocks. Turning to the employment regressions, the results of the spatial model are also consistent, except for the fact that the coefficient for the diversity index is no longer significant at the $10 \%$ level. The sign of the coefficients are still positive in all cases, however, which is in line with our previous findings. 
Overall, we therefore conclude that our main findings are no artefacts of the spatial units of observations, as they are robust to explicitly accounting for spatially correlated errors.

\subsection{Endogeneity}

As argued above, foreign workers may not causally affect regional productivity and wages, but instead endogenously self-select into particular locations. Especially with respect to the wage regression our estimations may therefore suffer from a problem of reverse causality, as workers may sort into high-wage locations. We have demonstrated above that a simple pooled OLS regression is clearly ill-equipped to distinguish between the effect of diversity on wages and the opposite effect of wages on migration flows, as it overstates the importance of the former channel. Introducing regional fixed effects reduces these concerns, but does not necessarily resolve them entirely. Furthermore, the share of foreign workers and the fractionalization index may capture the true effects of cultural diversity only imperfectly, so that OLS estimates would be biased due to measurement error. To address these concerns we turn to an instrumental variable estimation of our panel model in this subsection.

This approach causes several conceptual difficulties when it comes to selecting suitable instrumental variables for cultural diversity. Firstly, to satisfy the exclusion restrictions instruments need to be correlated with the geographical distribution of foreign workers, but not with current regional wages or productivities. Secondly, the instruments need to vary across regions and time. Thirdly, since we have two endogenous variables (the share of foreign workers and the diversity index), we need at least two instrumental variables.

We have considered several possible instrumental variables. Our primary set of instruments for the current diversity are time-lagged diversity variables of the same region. Specifically, we use second-order time lags of the share of (high-skilled or low-skilled) foreign workers and the respective twice lagged Herfindahl diversity indices. According to a standard Sargantest these second-order lags (unlike first-order lags) are suitable instruments for the current levels of cultural diversity. Furthermore, apart from passing validity tests, one should also verify if the chosen instruments have sufficient explanatory power, as weak instruments would lead to poor finite-sample properties regarding bias and size of significance tests (Bound et al. 1995). As we have to instrument two endogenous variables, a simple F-test of the joint significance of the instruments in a first-stage regression can be misleading, but we use the Cragg-Donald statistic instead. ${ }^{12}$ When considering the second-order time lags of the

\footnotetext{
12 The Cragg-Donald statistic is the minimum Eigenvalue of the generalized F-statistic from the fist-stage regressions. Stock and Yogo (2005) provide pre-determined critical values for this statistic under which the size of a nominal 5 percent Wald test on a regression coefficient is actually at least 10 percent.
} 
diversity variables, we not only find that the Sargan-test cannot reject the null of exogeneity, but also that these instruments appear to be strong.

As we do not want to rely exclusively on time-lagged control variables as instruments, however, we have furthermore considered three other variables, all of which fulfil the requirements for exogenous and strong instruments according to the Sargan- and the CraggDonald test. Firstly, we use the fertility of the regional foreign populations, more precisely the share of foreign babies in all regional births per year, and the number of foreign babies per foreign employee in every region and year. Both fertility-related variables are likely to be correlated with the size and characteristics of the foreign workers in a region, but unlikely to be correlated with the labour market performance of native workers. Secondly, we use the regional vote shares of the Green party in the national elections (Bundestagswahlen). ${ }^{13}$ This variable may be regarded as a proxy for the tolerance of the native populations towards foreigners, but is per se unlikely to exert an effect on the labour market performance of native workers. Thirdly, we use historical regional employment shares of classical guest worker industries. As described above, the guest worker families represented the first large immigration wave to Western Germany after World War II. The guest workers typically found employment in industries with low formal skill requirements. We consider mining, building\& construction, gastronomy and household-related services as typical guest worker industries, and we construct time-varying regional employment shares of these industries. Our data for this instrument starts with the year 1977, which is in fact the earliest time period for which we can obtain reliable regional labour market data and 18 years before the start of our observation period. These lagged industrial structures have determined historical location patterns of immigrants across Germany, and are thus likely to be correlated with the current geographical distribution of families with migration background due to the of persistence of migration networks. At the same time these historical local industry compositions are less likely to have an effect on current economic performance, because the importance of the classical guest worker industries for aggregate economic activity has rapidly diminished over time. ${ }^{14}$ Table $6 \mathrm{a}$ and $6 \mathrm{~b}$ summarize the results of the wage regression controlling for the share and the diversification of high-skilled and low-skilled foreign workers, respectively. ${ }^{15}$

\footnotetext{
${ }^{13}$ As national elections take place only every four years, we extrapolate the regional vote shares for the years in between elections in order to have a consistent time-variant instrument.

${ }^{14}$ See Findeisen and Südekum (2008) for an analysis of structural change at the regional level in Germany.

${ }^{15}$ In their analysis for the US, Ottaviano and Peri (2005) use two types of instruments: 1) the geographical distance of metropolitan areas to major immigration hubs, 2) a "shift-share instrument" that calculates hypothetical local diversity indices from employment growth rates for workers from particular foreign nationalities in the country as a whole. We have experimented with similar instruments, but these variables did not pass our specification tests. In particular, we have considered the regional distance to exterior borders of
} 


\section{TABLE 6 HERE}

In the first columns of panels $\mathrm{A}$ and $\mathrm{B}$ we report the results of the standard fixed effects estimation as a benchmark. The other columns refer to estimations where we use the timelagged diversity variables and one or more of the above mentioned other variables as instruments. As mentioned before, all these specifications pass the standard Sargan test for exogenous and the Cragg-Donald test for strong instruments. Again we focus on the main coefficients of interest while leaving out the other regional controls for brevity.

For the high-skilled foreign workers we still find that both their share and their diversification have positive effects on the regional average wage for native workers. The share of lowskilled foreign workers has a negative effect, but there are still positive wage effects associated with the diversification of this group. Comparing the standard fixed effects and the instrumental variable regressions, we find much larger effects with the latter approach. In principle, such a notable difference between the estimated coefficients could be caused by a weak instrument problem which leads to a large bias of the IV estimates. However, the CraggDonald test suggests that this is not the case in our analysis. An alternative explanation for the difference in the coefficients is that our diversity indices may be noisy measures for the "true" impact of cultural diversity on local labour markets. The larger coefficients in the instrumental variable regressions (in absolute terms) would then result from a reduction in the attenuation bias that results from the measurement error of the variable $\operatorname{div}_{r, t}$. In that case the "true" effect of cultural diversity is actually closer to the coefficient of the instrumental variable estimation.

Summing up, our main results remain qualitatively robust when treating the qualificationspecific shares of foreign workers and the respective diversification indices as endogenous. In fact, the instrumental variable estimation gives us reason to believe that the "true" effects of cultural diversity were even understated in the benchmark analysis in section 4 .

\section{6) Conclusions}

Skilled foreign workers affect native employees on regional labour markets quite differently than low-skilled foreign workers. The presence of high-skilled foreign workers can be regarded as a positive production amenity from a regional perspective, especially if this group is diversified in terms of national and cultural backgrounds. For low-skilled foreign workers

Germany interacted with a time dummy. This instrument has almost no explanatory power, however, which is probably due to the relatively small geographical size of Western Germany compared to the US. The shift-share instrument did not pass the instrument validity test. 
results are different. The larger is the size of this group, the lower is regional productivity. Yet, conditional on the size of the low-skilled foreign workforce, we still find positive productivity effects associated with their diversification. These conclusions turn out to be robust to several estimation concerns.

These finding have important implications for the policy debate about the principles of immigration to Germany. This debate has strongly focussed on the skill composition of the immigrants. It led to several attempts to target high-skilled foreign immigrants in specific industries where native specialists are in short supply (e.g., in the IT business). The cultural diversity of the immigrants, i.e., the composition of the overall group of immigrants in terms of foreign nationalities, has so far played a minor role in this debate. Our results suggest that there are returns to cultural diversity in regional labour markets, and that immigration policy can consequently be improved by taking these aspects into account. Moreover our results suggest that multiculturalism has rather tangible effects. The impacts do not appear to be mainly transmitted through "soft" location factors that shape the perceptions about the quality of life in different locations, but the primary effects seem to be on regional productivity.

\section{References}

Alesina, A., Baqir, R., Easterly, W. (1999) Public goods and ethnic divisions, Quarterly Journal of Economics 114: 1243-84

Alesina, A., Baqir, R., Easterly, W. (2000) Redistributive public employment, Journal of Urban Economics 48: 219-41

Alesina, A., La Ferrara, E. (2005) Ethnic diversity and economic performance, Journal of Economic Literature 43: 762-800

Alesina, A., La Ferrara, E. (2002) Who trusts others?, Journal of Public Economics 85: 207-34

Anselin, L. (1988) Spatial econometrics: methods and models. Boston: Kluwer

Audretsch, D., Feldman, M. (1996) R\&D spillovers and the geography of innovation and production, American Economic Review 86: 630-640

Berliant, M., Fujita, M. (2008) Knowledge creation as a square dance on the Hilbert cube, International Economic Review 49: 1251-1295

Bonin, H. (2005) Wage and employment effects of immigration to Germany: Evidence from a skill group approach. IZA Discussion Paper No. 1875, Bonn

Borjas, G. (1994) The economics of immigration, Journal of Economic Literature 32: 1667-1717

Bound, J., Jaeger, D.A., Baker, R.M. (1995) Problems with instrumental variables estimation when the correlation between instruments and the endogenous explanatory variables is weak, Journal of the American Statistical Association 90: 443-450 
Brücker, H., Jahn, E. (2009) Migration and wage-setting - Reassessing the labor market effects of migration, Kiel Working Paper 1502

Card, D. (2001) Immigrant inflows, native outflows and the local labor market impacts of higher immigration, Journal of Labor Economics 19: 22-61

D'Amuri, F., Ottaviano, G., Peri, G. (2009) The labour market impact of immigration in Western Germany in the 1990's, forthcoming: European Economic Review

De New, J., Zimmermann, K. (1994) Native wage impacts of foreign labor: a random effects panel analysis, Journal of Population Economics 7: 177-192

Desmet, K., Ortuno-Ortin, I., Wacziarg, R. (2009) The political economy of ethnolinguistic cleavages, NBER Working Paper 15360, Cambridge (Mass.)

Dustmann, C., Glitz, A. (2005) Immigration, jobs and wages: theory, evidence and opinion, CEPR Report, London

Dustmann, C., Preston, I. (2001) Attitudes to ethnic minorities, ethnic context and location decisions, Economic Journal 111: 353-373

Easterly, W., Levine, R. (1997) Africa's growth tragedy: policies and ethnic divisions, Quarterly Journal of Economics 112: 1203-50

Florida, R. (2002) Bohemia and economic geography, Journal of Economic Geography 2: 55-71

Findeisen, S., Südekum, J. (2008) Industry churning and the evolution of cities: evidence for Germany, Journal of Urban Economics 64: 326-339

Friedberg, R., Hunt, J. (1995) The impact of immigration on host country wages, employment and growth, Journal of Economic Perspectives 9: 23-44

Glaeser, E., Laibson, D., Scheinkman, J., Soutter, C. (2000) Measuring trust, Quarterly Journal of Economics 115: 811-46

Glaeser, E., Scheinkman, J., Shleifer, A. (1995), Economic growth in a cross-section of cities, Journal of Monetary Economics 36: 117-43

Glitz, A. (2007) The labour market impact of immigration: quasi-experimental evidence, mimeo, University of Pompeu-Fabra

Haas, A., Damelang, A. (2007) Labour market entry of migrants in Germany - Does cultural diversity matter? IAB Discussion Paper, 18/2007, Nuernberg

Hong, L., Page, S. (2001) Problem solving by heterogeneous agents, Journal of Economic Theory 97: 123-163

Kapoor, M., Kelejian, H.H., Prucha, I.R. (2007) Panel data models with spatially correlated error components, Journal of Econometrics 140: 97-130

Lazear, E. (1999) Culture and languages, Journal of Political Economy 107: 95-126

Mutl, J., Pfaffermayr, M. (2008) The spatial random effects and the spatial fixed effects model: the Hausman test in a Cliff and Ord Panel Model, Discussion Paper 229, Institute for Advanced Studies, Vienna 
Niebuhr, A. (2006): Migration and innovation. Does cultural diversity matter for regional R\&D activity? IAB Discussion Paper, 14/2006, forthcoming in: Papers in Regional Science

Ottaviano, G., Peri, G. (2005) Cities and cultures, Journal of Urban Economics 58: 304-337

Ottaviano, G., Peri, G. (2006), The economic value of culture diversity: evidence from US cities, Journal of Economic Geography 6: 9-44

Pischke, S., Velling, J. (1997) Employment effects of immigration to Germany: an analysis based on local labor markets, Review of Economics and Statistics 79: 594-604

Roback, J. (1982) Wages, rents and the quality of life, Journal of Political Economy 90: 1257-78

Schmidt, C., Stiltz, A., Zimmermann, K. (1994) Mass migration, unions, and government intervention, Journal of Public Economics 55: 185-201

Spolaore, E., Wacziarg, R. (2009) The diffusion of development, Quarterly Journal of Economics 124: 469-529

Stock, J.H., Yogo, M. (2005) Testing for weak instruments in linear IV regression, in: Stock, J.H., Andrews, D.W.K. (eds), Identification and inference for econometric models, Cambridge University Press

Zimmermann, K. (2005) European migration: what do we know? Oxford University Press

Zimmermann, K., Bonin, H., Fahr, R., Hinte, H. (2007) Immigration policy and the labor market. Berlin: Springer 
Figure 1: Foreign worksers in the West German labour market

Figure 1a: Share of foreign workers in total full-time employment, West Germany, 1995-2006

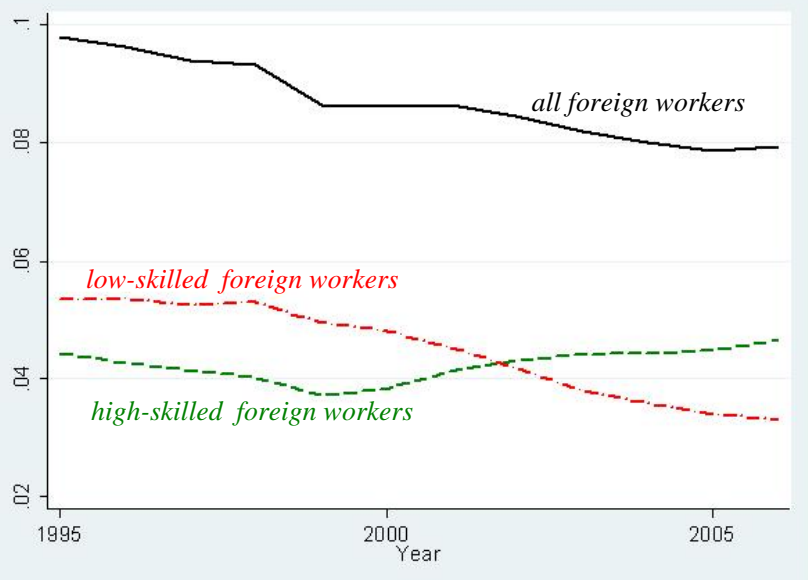

Figure 1b: Diversity within the group of foreigners (Herfindahl-index), West Germany, 1995-2006

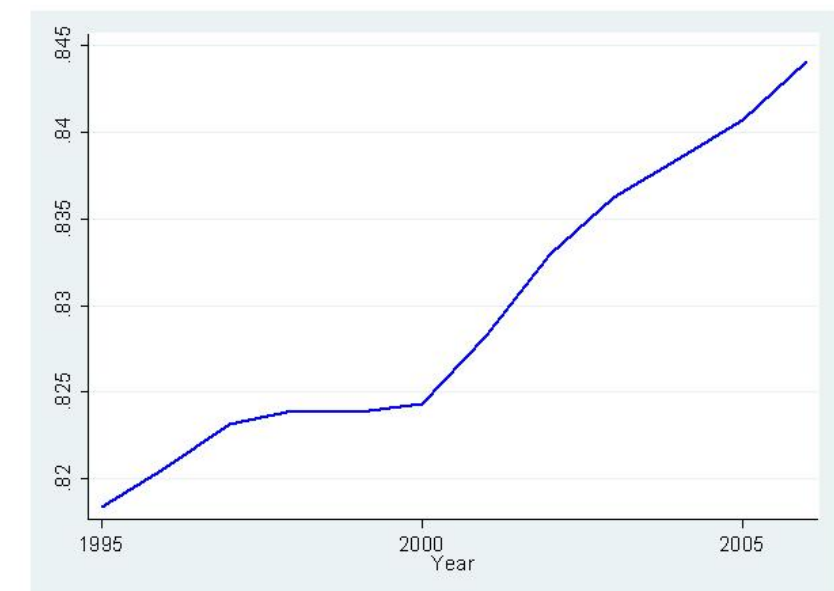


Figure 2: The identification approach

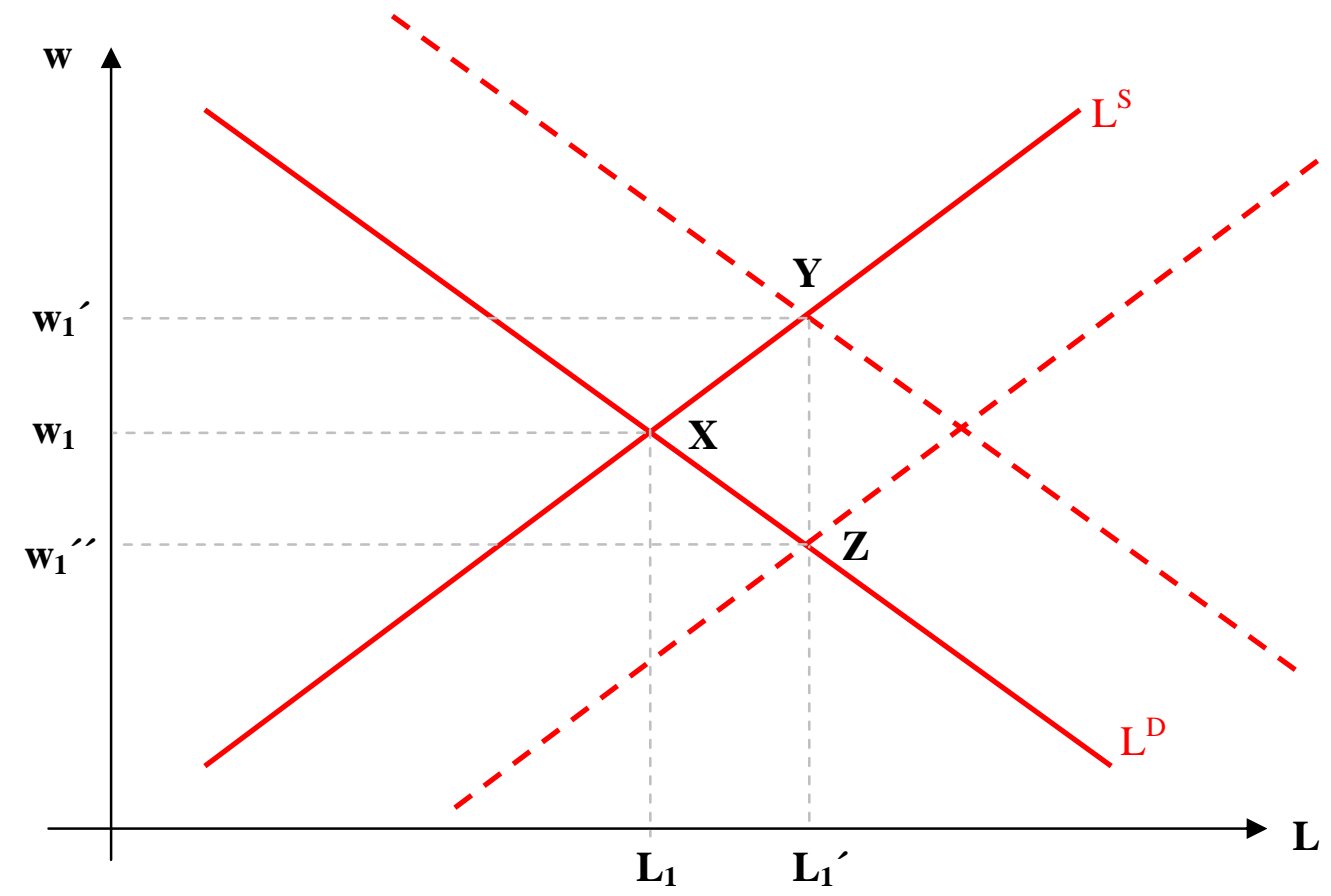




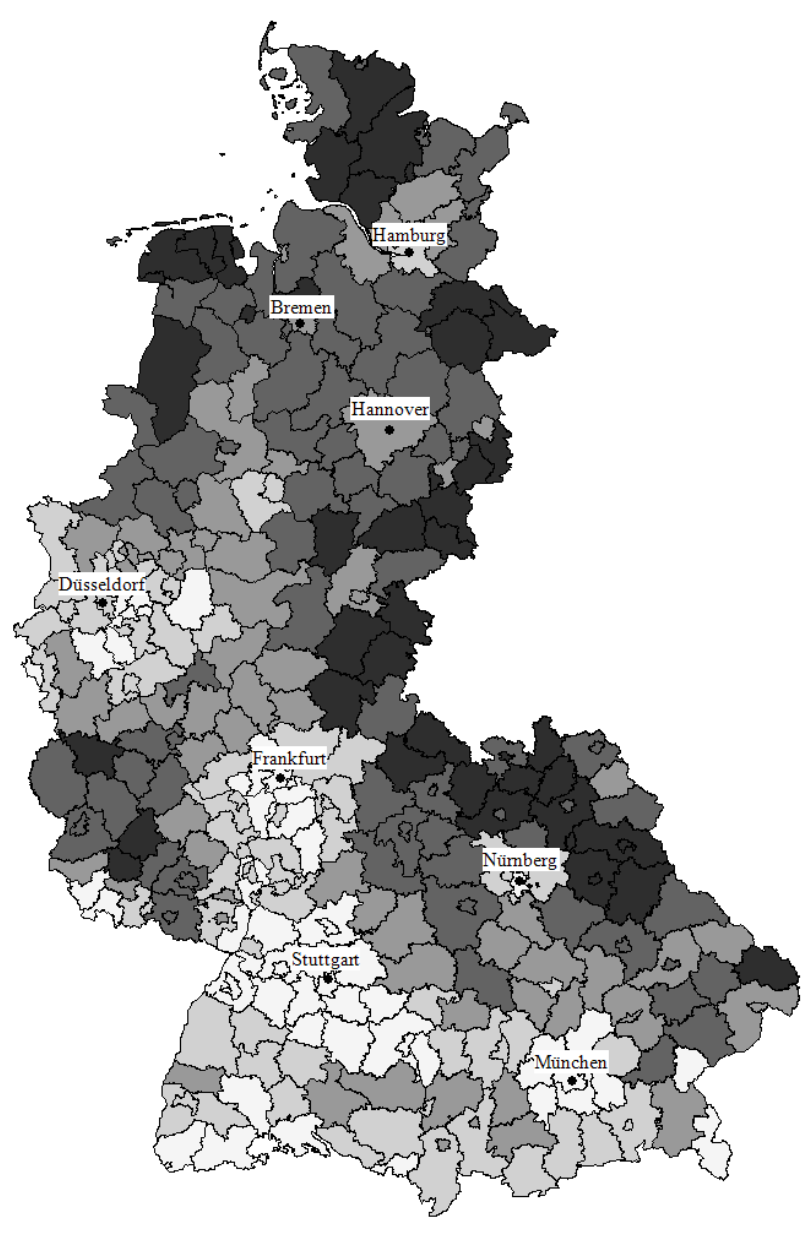

\section{Total share of foreigners}

froen 0.01 to $0.03(44)$

from 0.03 to 0.05 (81)

ficen 0.05 to $0.07(69)$

froen 0.07 to $0.10(76)$

froen 0.10 to $0.16(56)$

Note: Map shows the shares of foreign employees in total regional full-time employment for the 326 Western German NUTS3-regions ("Kreise" and "kreisfreie Städte”) for the year 2006. 
Table 1: Largest foreign nationalities in Western Germany (in \%)

\begin{tabular}{|c|c|c|c|c|}
\hline Rank & \multicolumn{2}{|c|}{1995} & \multicolumn{2}{c|}{ To06 } \\
\hline 1 & Turkey & 28.24 & frm. Yugoslavia & 14.43 \\
\hline 2 & frm. Yugoslavia & 19.92 & Italy & 10.35 \\
\hline 3 & Italy & 10.06 & Greece & 5.00 \\
\hline 4 & Greece & 5.58 & frm. Soviet Union & 4.55 \\
\hline 5 & Austria & 3.95 & Poland & 4.19 \\
\hline 6 & France & 3.35 & France & 4.06 \\
\hline 7 & Poland & 3.01 & Austria & 3.11 \\
\hline 9 & Portugal & 2.51 & Portugal & 2.38 \\
\hline 10 & Spain & 2.41 & Spain & 1.91 \\
\hline
\end{tabular}

Note: Table 1 shows the ten largest share of nationality $\mathrm{k}$ in the total population of foreign full-time employees for Western Germany and for the years 1995 and 2006 (in per cent).

Table 2: Labour market participation of foreigners in selected cities 2006

\begin{tabular}{|l|c|c|c|c|c|}
\hline City & \multicolumn{2}{|c|}{$\begin{array}{c}\text { Total } \\
\text { employment }\end{array}$} & \multicolumn{2}{|c|}{$\begin{array}{c}\text { Total share of } \\
\text { foreign workers (\%) }\end{array}$} & \multicolumn{2}{c|}{$\begin{array}{c}\text { Diversity index, } \\
\text { foreign employees }\end{array}$} \\
\hline & (native + foreign) & all & high-skilled & All & high-skilled \\
\hline Hamburg & 633,311 & 7.24 & 4.68 & 0.9160 & 0.9539 \\
\hline Munich & 563,931 & 14.53 & 7.63 & 0.8913 & 0.9328 \\
\hline Frankfurt & 396,702 & 13.85 & 7.00 & 0.9140 & 0.9545 \\
\hline Cologne & 369,060 & 10.21 & 5.15 & 0.8243 & 0.9493 \\
\hline Hannover & 335,503 & 6.24 & 4.15 & 0.8781 & 0.9529 \\
\hline Duesseldorf & 293,208 & 9.65 & 5.88 & 0.9137 & 0.9548 \\
\hline Stuttgart & 286,546 & 13.49 & 5.96 & 0.8685 & 0.9476 \\
\hline & & & & & \\
\hline $\begin{array}{l}\text { Ø WESTERN } \\
\text { GERMANY }\end{array}$ & & $\mathbf{6 . 5 6}$ & $\mathbf{4 . 2 1}$ & $\mathbf{0 . 8 3 7 0}$ & $\mathbf{0 . 9 0 3 2}$ \\
\hline
\end{tabular}




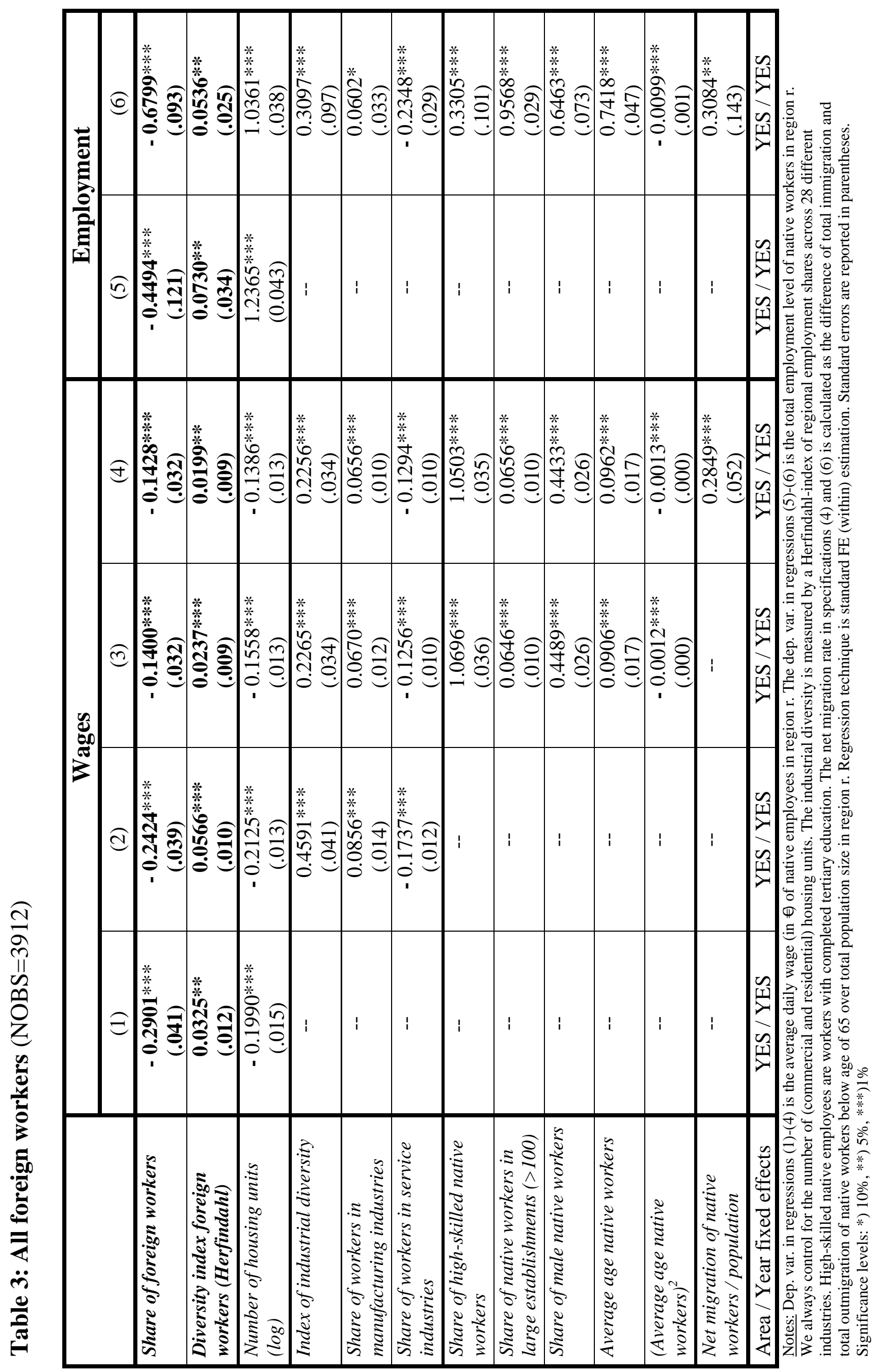



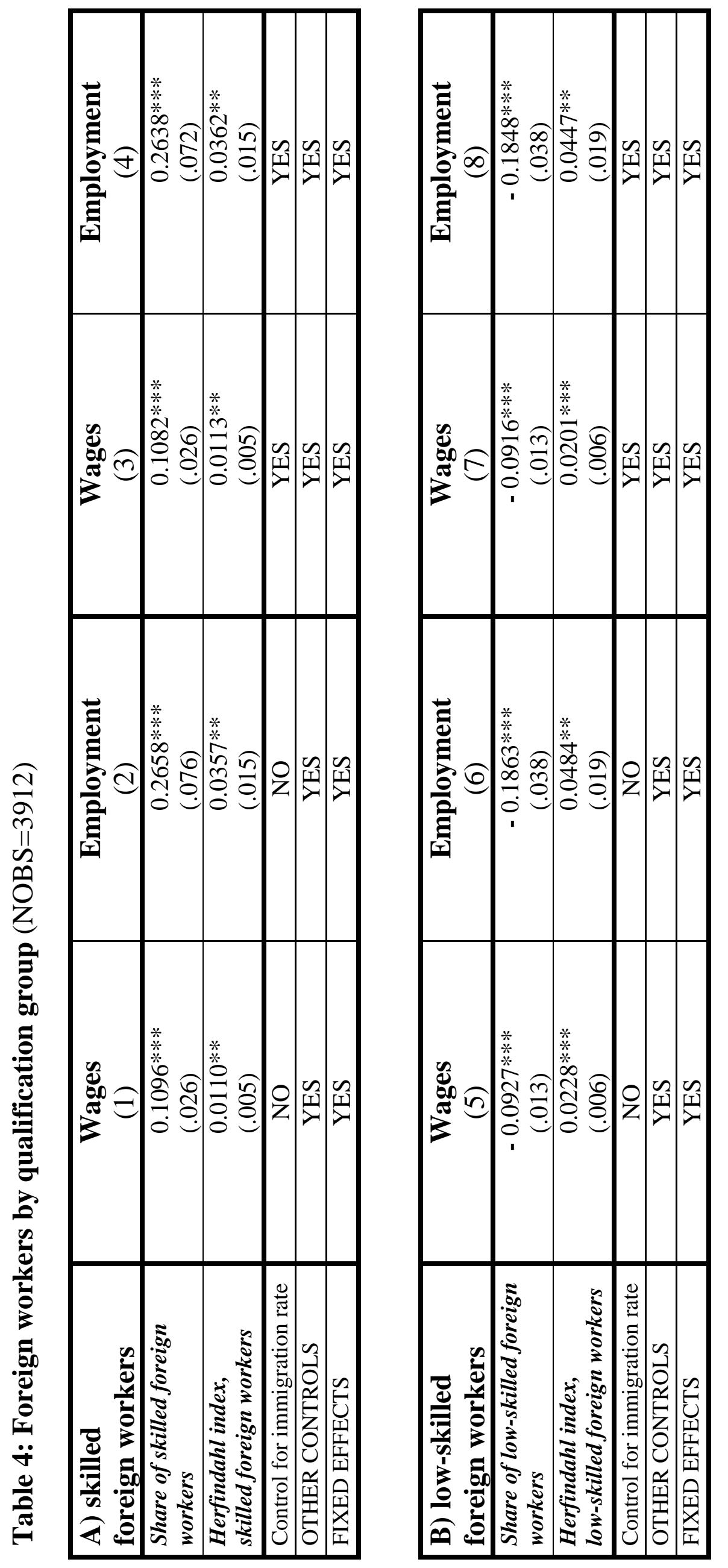

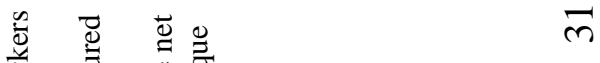

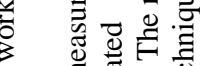

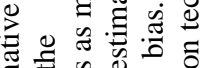

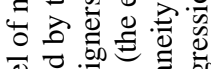

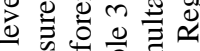

记

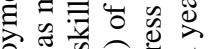

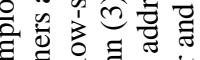

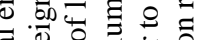

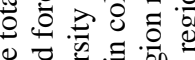

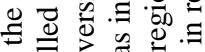

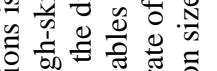

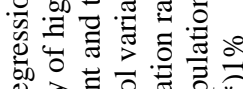

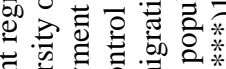

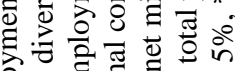

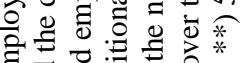

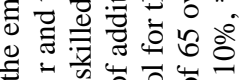

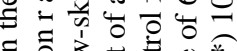

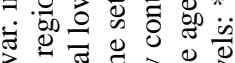

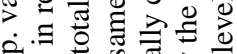

ष्ष

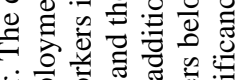

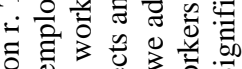

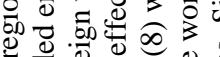

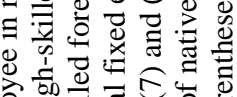

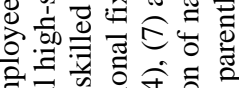

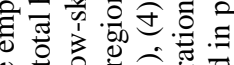

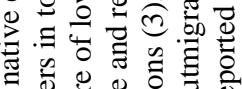

踏范

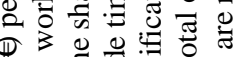

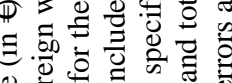

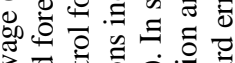

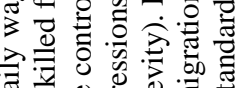

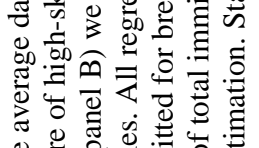

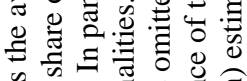

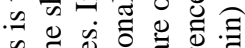

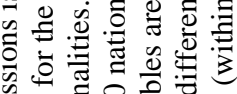

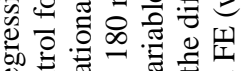

인

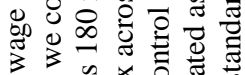

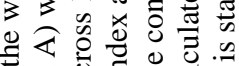

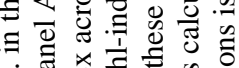

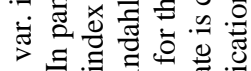

证谓

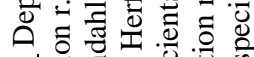

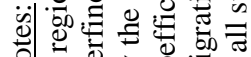



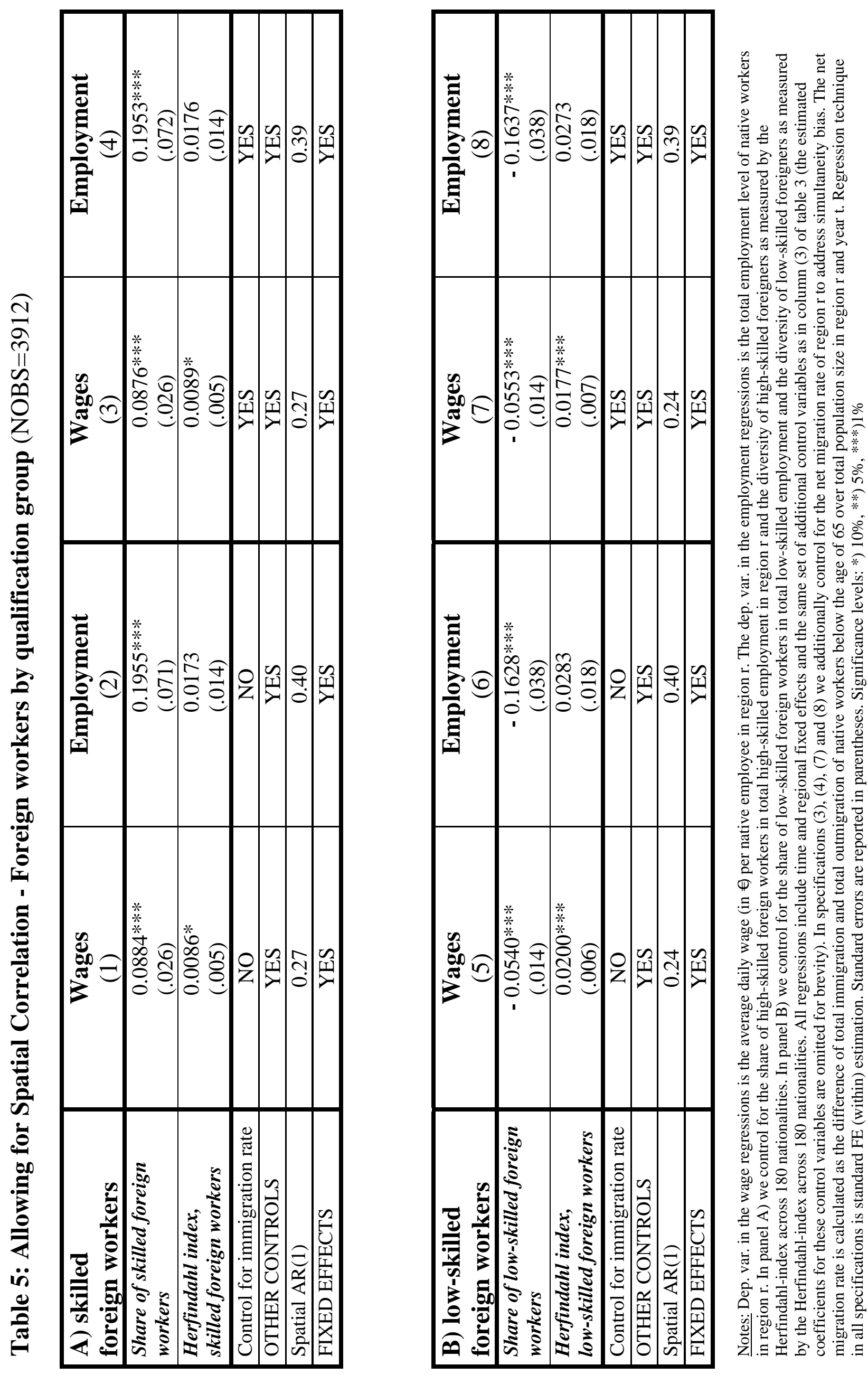


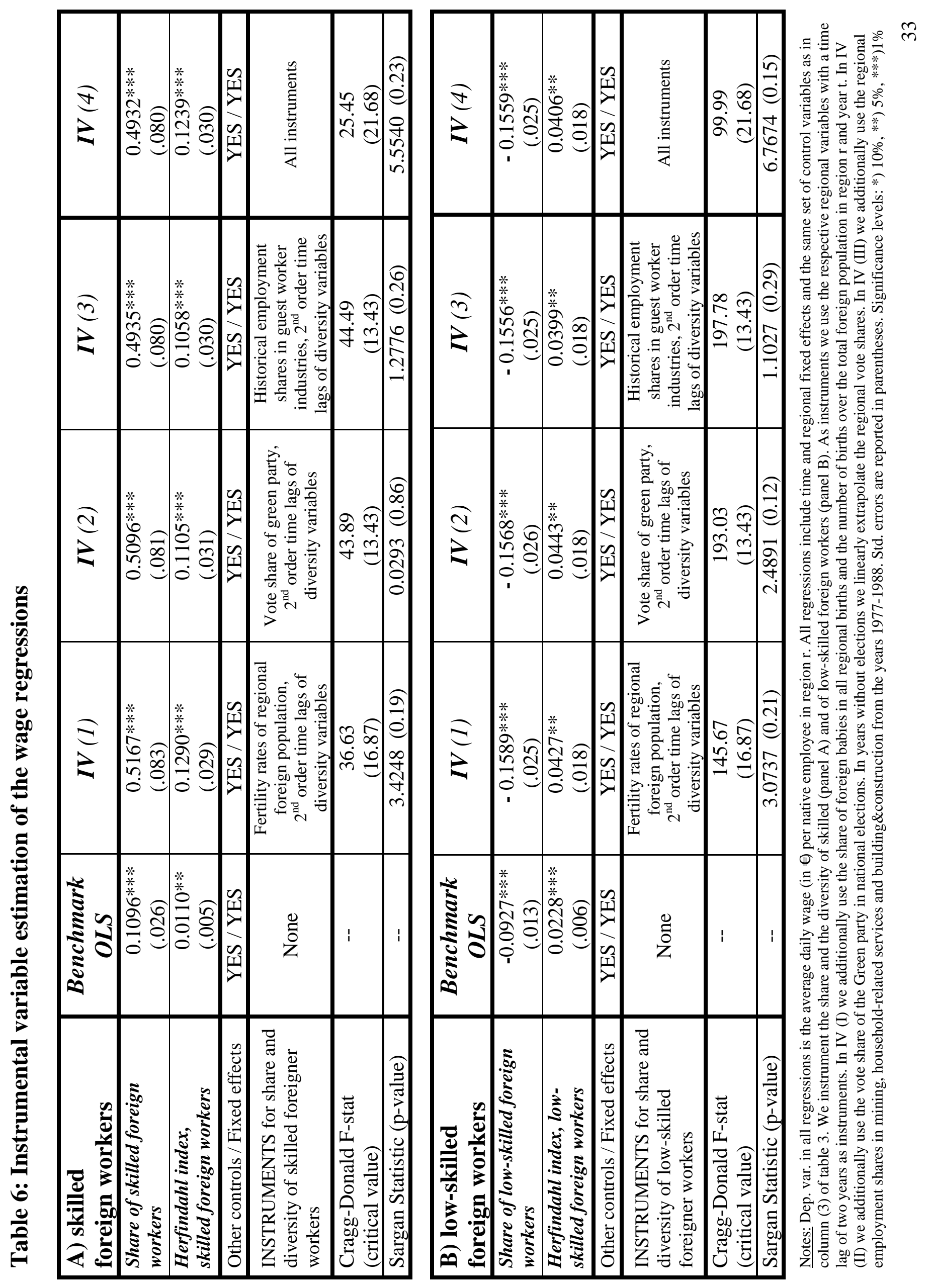

